Session 2139

\title{
CALCULATING $i$ FROM FINANCIAL DATA: A LONGITUDINAL ANALYSIS OF CONSTRUCTION RELATED FIRMS
}

\author{
Mike Loose, Dr. Ted Eschenbach, P.E., Dr. John Whittaker \\ University of Alberta / TGE Consulting / University of Alberta
}

\begin{abstract}
The interest rate, $i$, for evaluating investments can be derived from the opportunity cost of capital or the cost of financing. This paper applies a variety of methods to calculate the latter using the published financial data of five publicly listed steel fabrication firms. This industry was chosen because it is part of engineering and construction, the firms have enough organizational continuity, and using a single industry controls for some sources of variability. This analysis is done over time to provide a longitudinal perspective on the stability and meaningfulness of the different proposed measures.
\end{abstract}

This research is intended to establish a data-based foundation for teaching students in engineering economy courses how to establish the minimum attractive rate of return. This paper will present results for this data set and discuss links with other ongoing research.

\section{Introduction}

The interest rate, $i$, for evaluating investments can be derived exogenously from the cost of financing or endogenously from the opportunity cost of capital (based on the budget and the available investment opportunities). In order to provide data for the broader debate, this paper applies a variety of the methods (such as weighted average cost of capital and marginal cost measures) for defining $i$ using the cost of financing (loans, bonds, stock, and retained earnings). To ensure comparability these firms are selected from publicly held corporations in a single industry listed on North American stock exchanges. This analysis is done over time to provide a longitudinal perspective on the stability and meaningfulness of the different proposed measures.

Steel fabrication firms were chosen for analysis, because of their close connection to the engineering and construction industry and because they have more organizational continuity than some areas of the E\&C industry. Also, most of their principals have had courses in engineering economy, so that seems likely to influence approaches used to establish minimum attractive rates of returns. Their engineers use engineering economy and this minimum attractive rate of return in designing buildings, bridges, etc. and in selecting equipment to accomplish the work.

This paper is the second in a series we are developing wherein we intend to examine the usefulness of proposed methods for defining the minimum attractive rate of return (MARR). The first paper, Shifting $i$ 's are not a Firm Foundation ${ }^{1}$ applied a variety of the methods for defining $i$ using the published financial data of eleven major corporations. The disparate results for the value of $i$ suggested limitations in the exogenously defined financial measures. Our intent is to examine a broader group of firms on an industry by industry basis to better delineate these limitations. This paper examines a single industry, steel fabricators and extends our analysis over 
time. Then, emboldened by our observations we advance some tentative conclusions of the veracity and applicability of the measures.

\section{Background Review}

Texts in finance and engineering economy suggest numerous techniques for calculating the cost of financing. Determining the rates for bonds or loans is a straight-forward. However, the cost of equity capital (stock and retained earnings) is more complicated. This paper, like Prescott

$(1999)^{2}$, examines the following methods:

Net equity flow method,

Marginal equity flow method, and

Capital asset pricing model (CAPM).

These values are combined with loans, leases, and bonds to compute the marginal cost of capital (MCC) and the weighted average cost of capital (WACC).

\section{Calculating the Cost of Equity Capital}

Net Equity Flow Method. Park (et al, p. 692) ${ }^{3}$ recommends using a weighted average cost of equity as follows.

$$
\begin{aligned}
& i_{e}=a \times k_{r}+b \times k_{e}+c \times k_{p} \\
& a+b+c=1 \\
& k_{r}=\frac{D_{0}}{P_{0}}+g \\
& k_{e}=\frac{D_{0}}{P_{0}\left(1-f_{c}\right)}+g \\
& k_{p}=\frac{D_{*}}{P_{*}\left(1-f_{c}\right)}
\end{aligned}
$$

$i_{\mathrm{e}}=$ Cost of equity

$\mathrm{a}=$ Fraction of total equity from retained earnings

$\mathrm{b}=$ Fraction of total equity from common stock

$\mathrm{c}=$ Fraction of equity financed from preferred stock

$\mathrm{P}_{0}=$ Market price

$\mathrm{D}_{0}=$ First year dividend

$\mathrm{g}=$ Growth rate of dividend

$\mathrm{f}_{\mathrm{c}}=$ Flotation cost as a percentage of common stock price (i.e. cost of issuing new stock)

$\mathrm{D}_{*}=$ Fixed annual dividend

$\mathrm{P}_{*}=$ Issuing price

$\mathrm{k}_{\mathrm{r}}=$ Cost of retained earnings

$\mathrm{k}_{\mathrm{e}}=$ Cost of common stock

$\mathrm{k}_{\mathrm{p}}=$ Cost of preferred stock

Marginal Net Equity Flow. The previous method can easily be converted to determine the marginal cost of equity by replacing the fraction financed from stock with the fraction financed from new stock. Similarly, the fractions financed from preferred stock and retained earnings are replaced with the fractions financed from new preferred stock and retained earnings respectively. 
The advantage of using the marginal cost of equity is that it more closely reflects the current sources of the firm's equity financing. The weighted average cost of equity determines the cost of equity based on the firm's overall equity composition, which may not be the same as its most recent financing composition.

Capital Asset Pricing Model. The capital asset pricing model (CAPM) was developed to explain the variation in yield rates on various types of investments and also to provide insight into the appropriate rate to use in discounted cash flow analysis (Kellison, p. 350). ${ }^{4}$ The main benefit is that it shows the relationship between project risk and return.

The CAPM identifies two types of risk. The first is unsystematic risk, also known as unique risk. This is the risk reflected in price movements that cannot be explained by collective market behaviour. The model assumes that unsystematic risk can be eliminated in a diversified portfolio and is therefore neglected. The second type of risk is systematic or market risk. This type of risk reflects price movements for the market as a whole and cannot be diversified away. The equation known as the CAPM is:

$$
\begin{aligned}
& \bar{R}=R_{F}+\beta \times\left(\bar{R}_{M}-R_{F}\right) \\
& \bar{R}=\text { Expected yield rate on an investment } \\
& R_{F}=\text { Risk-free rate of interest } \\
& \beta=\text { Beta, measures the systematic risk } \\
& \bar{R}_{M}=\text { Yield rate on the market portfolio }
\end{aligned}
$$

This means that "the expected return on an investment depends on the investment's risk relative to the risk of a market portfolio" (Ross et al, p. 310) ${ }^{5}$. This equation is based on two assumptions ${ }^{5}$ :

1. All individuals have homogeneous expectations

2. All individuals can borrow and lend at the risk-free rate

The general practice for determining the risk-free rate of interest is to use the yield to maturity on 10 -year government securities (Weston et al, p. 189) ${ }^{6}$. From the firm's point of view, the expected return of the investment is the cost of equity capital (Ross et al, p.344) ${ }^{5}$. Of the four variables in the equation, only $\beta$ is difficult to understand and determine. "Researchers have shown that the best measure of risk of a security in a large portfolio is the beta of the security" (Ross et al, p.304) ${ }^{5}$. The large portfolio is actually a market value weighted portfolio of all existing securities, known as the market portfolio. In practice, this is estimated using a broadbased index such as the Toronto Stock Exchange 300 Index (TSE 300).

Generally, the last term of the CAPM, $\left(\bar{R}_{m}-\bar{R}_{f}\right)$, is known as the market risk premium and is about $6 \%$, based on historical evidence (Stewart, p. 438$)^{7}$.

The ${ }^{\beta}$ for security ' $i$ ' is found using, (Ross et al, p. 304) ${ }^{5}$

$$
\begin{aligned}
& \beta_{i}=\frac{\operatorname{Cov}\left(R_{i}, R_{M}\right)}{\sigma^{2}\left(R_{M}\right)} \\
& \operatorname{Cov}\left(R_{i}, R_{M}\right)=\text { Covariance between security } \mathrm{i}\left(\mathrm{R}_{\mathrm{i}}\right) \text { and the market portfolio }\left(\mathrm{R}_{\mathrm{M}}\right) \\
& \sigma^{2}\left(R_{M}\right)=\text { Variance of the market }
\end{aligned}
$$


From these equations, it is evident that beta is an indicator of the sensitivity of change in the return of an individual security to the change in the market portfolio's return.

\section{Determining the MARR}

The MARR is sometimes the cost of equity, but more often it also includes the cost of debt. The logic of using the cost of equity as the value for MARR is succinctly explained by Park when he states "...the goal of the firm is to maximize the wealth of the stockholders, [the focus should be] only on the after-tax cash flow to equity, instead of on the flow to all suppliers of capital" (Park et al, p.697) ${ }^{3}$.

Weighted Average Cost of Capital (WACC). The reasoning behind using the WACC as the MARR is as follows. In order to be acceptable, the project must have a higher rate of return than the cost of raising capital. The cost of capital is the minimum rate of return on capital required to compensate debt and equity investors for bearing risk (Dierks \& Patel) ${ }^{8}$.

The calculation of the cost of capital is shown below, where the MARR is assumed to equal the WACC.

$$
\begin{aligned}
& W A C C=\frac{i_{d} \times D}{V}+\frac{i_{e} \times E}{V} \\
& V=D+E
\end{aligned}
$$

Where:

$i_{\mathrm{e}}=$ Average equity interest rate per period considering all equity sources

$i_{\mathrm{d}}=$ After-tax average borrowing interest rate per period considering all debt sources

$\mathrm{D}=$ Total debt capital in dollars

$\mathrm{E}=$ Total equity in dollars

Marginal Cost of Capital (MCC). If each source of funds is restricted to new or prospective funds, then the formulas above compute the marginal rather than the average cost of capital. Also both the average and the marginal methods can be computed using the different approaches for the cost of equity.

\section{Methodology}

This methodology begins by choosing companies from a specific industry sector that has strong ties to engineering economy. The selection of a specific sector allows greater probability that mergers and divestitures stay within the data set.

To guide the search for five corporations out of thousands, we used the following criteria:

1. be based in the United States,

2. be a parent company,

3. be a competitor in the same sector of industry as the other four corporations,

4. have been incorporated prior to 1980 ,

5. be void of major mergers from 1980 to 2002 that significantly changed the nature of business

6. pay annual dividends. 
Fortunately, the internet and the major business data bases make this task possible. Among the many tools offered by the University of Alberta's Winspear Business Reference Library, we found FISonline and InfoGlobe Dow Jones Interactive to be the most useful. Together their differing perspectives proved to be sufficient to satisfy these constraints.

\section{Screening Candidates}

Identifying candidates for this research became a two step process:

Step 1: $\quad$ Use Dow Jones Interactive to search for dividend paying corporations within a specific industry sector (this search would be for one year only, normally from 2002 quarterly reports).

Step 2: $\quad$ Use Dow Jones Interactive and FISonline as shown in Table 1 to identify which corporations from step 1 meet the screening criteria.

\begin{tabular}{|l|c|c|}
\hline \multirow{2}{*}{ Screening Criteria } & \multicolumn{2}{|c|}{ Database(s) queried: } \\
\cline { 2 - 3 } & FISonline & DowJones \\
\hline U.S. based? & $\mathrm{X}$ & \\
\hline A parent company? & $\mathrm{X}$ & \\
\hline Competitive with other candidates? & $\mathrm{X}$ & $\mathrm{X}$ \\
\hline Incorporated prior to 1980? & $\mathrm{X}$ & \\
\hline Void of major mergers? & $\mathrm{X}$ & \\
\hline Paid an annual dividend each year $(1991-2001) ?$ & $\mathrm{X}$ & $\mathrm{X}$ \\
\hline
\end{tabular}

Table 1. Use of Databases in Step 2 of Candidate Screening

Six screening trials with varying organization and resources were completed before the seventh and final screening identified forty-two candidates in Step 1. After Step 2 screening there were eight remaining candidates from which five were selected for the research.

\section{Selecting Candidates}

The selection of the final five candidates was determined by examining the competitiveness between the eight corporations, where competitiveness is defined as a corporation's effort to manufacture and sell an identical or substitute product as another corporation.

The Corporation Finance Division of the United States Securities and Exchange Commission (SEC) has defined a series of Standard Industrial Classification (SIC) codes. These codes are used by many database providers to sort corporations. Thus, a comparison of primary SIC codes and an examination of a corporation's product mix (i.e. visiting their website or a database source) allow a rough assessment of the competitiveness of a group of corporations. Table 2 lists the five firms making up our final sample. 


\begin{tabular}{|l|c|l|}
\hline Name of Corporation & $\begin{array}{c}\text { Ticker } \\
\text { Symbol }\end{array}$ & Headquarters \\
\hline Carpenter Technology Corporation & CRS & Wyomissing, PA \\
\hline Commercial Metals Company & CMC & Dallas, TX \\
\hline Nucor Corporation & NUE & Charlotte, NC \\
\hline Quanex Corporaton & NX & Houston, TX \\
\hline Roanoke Electric Steel Corporation & RESC & Roanoke, VA \\
\hline
\end{tabular}

Table 2. List of Five Selected Corporations

\section{Performing Cost of Equity Calculations}

Before finalizing the sample, cost of equity calculations were performed for each corporation for the 2001 fiscal year. Calculations were made for net equity flow, marginal net equity flow, capital asset pricing model (CAPM), weighted average cost of capital (WACC). These calculations required more information from the databases shown in Table 3.

\begin{tabular}{|l|c|c|c|c|}
\hline $\begin{array}{c}\text { Cost of Capital Calculation } \\
\text { Method }\end{array}$ & $\begin{array}{c}\text { Corporate } \\
\text { Annual } \\
\text { Report }\end{array}$ & $\begin{array}{c}\text { Standard \& } \\
\text { Poor's } \\
\text { NetAdvantage }\end{array}$ & $\begin{array}{c}\text { Yahoo! } \\
\text { Financial }\end{array}$ & $\begin{array}{c}\text { Clearstation. } \\
\text { etrade.com } \\
\text { Beta }\end{array}$ \\
\hline Net equity flow & $\mathrm{X}$ & & $\mathrm{X}$ & \\
\hline Marginal net equity flow & $\mathrm{X}$ & & $\mathrm{X}$ & \\
\hline CAPM & $\mathrm{X}$ & $\mathrm{X}$ & & $\mathrm{X}$ \\
\hline WACC \& net equity flow & $\mathrm{X}$ & $\mathrm{X}$ & & \\
\hline $\begin{array}{l}\text { WACC \& marginal net } \\
\text { equity flow }\end{array}$ & $\mathrm{X}$ & $\mathrm{X}$ & & \\
\hline
\end{tabular}

Table 3. Information Sources for Cost of Equity Calculations

In general the cost of equity calculations were straightforward but there are some concerns that will be discussed.

\section{Net Equity Flow Method}

- Flotation costs of $7.00 \%$ from Prescott $^{2}$ (1997) were used here.

- Market price of common and preferred stock was taken as the fiscal year end value. Given the sensitivity of some values to the stock's market price, use of an annual or weighted average must be explored.

\section{Marginal Net Equity Flow Method}

- New issues of common stock were determined by evaluating the difference in paid-in capital. It was observed that many new issues resulted from stock options - with a price different than the market value. Further investigation is required to determine the appropriate way to determine the value of new common stock, whether the price is the exercise price or the market value.

- Another scenario with new issues of common stock is when amount $\mathrm{X}$ is issued, but the corporation buys back amount $\mathrm{Y}$ (where $\mathrm{X}>\mathrm{Y}$ ). Is the amount of new stock issued $\mathrm{X}$, or is it $\mathrm{X}-\mathrm{Y}$ ? Again, a concern to be addressed. 


\section{$C A P M$}

- $\mathrm{R}_{\mathrm{m}}-\mathrm{R}_{\mathrm{f}}$, known as the "market risk premium" has been shown to be about $6 \%$.

$W A C C$

- The calculations completed in this paper have included the current portion of long term debt in the total debt parameter (debentures \& bonds + bank loans).

\section{Observations and Discussion}

The starting point of this paper had been our earlier one ${ }^{1}$ wherein we observed the results of calculating values for eleven different companies. There we observed:

"The range of answers, with $i$ values shifting wildly within and between companies, indicates that the methods for calculating $i$ are incompatible. Even though this is only a small convenience sample, it is more than adequate to demonstrate the inconsistent results produced from using different methods of calculating $i$. Since only one method was used to determine the cost of debt, the differences in the $i$ 's result from the methods used to calculate the cost of equity. Consequently, this discussion will focus on the cost of equity results. The table shows the remarkable differences between the costs of equity calculated for each company. The net equity flow method and the marginal net equity flow method generally yield similar results, but differ greatly from the costs of equity determined using the CAPM."

The present data, Table 4, reinforces those conclusions and also add the longitudinal dimension. For example, the most stable net equity flow time series, Carpenter Technologies Corp, has a MARR value that more than doubles from 3\% one year to $6.5 \%$ two years later. What confusion would this introduce into a project group and would they be advised to try to extricate themselves from the previously accepted 3\% projects? Should the person whose favorite project has just been rejected plan on simply waiting for a lower rate? Nucor Corporation, with a range of net equity flow rates of $45 \%+$ has magnified the problem. One year a $13 \%$ hurdle rate, the next year a $46 \%$ one.

The between companies comparison is also revealing. The basis of selection was publicly traded, dividend paying companies that compete with each other. Further, they are in the steel industry which is a mature industry, requiring high capital investment and possessing relatively stable technology. Thus one might expect that the MARR values would be reasonably similar. The results show the opposite, with net equity numbers varying from $2 \%$ to $46 \%$.

The only measure that appears reasonably stable over time is the CAPM and this has more to do with its assumptions and derivation than with actual data within the company. Based as it is on market measures, expected yield and risk free rate, and a beta which is calculated on the long term stock price risk relative to the market, there is no reason for it to vary.

Our earlier paper suggested that the MARR values calculated from internal data could perhaps form a lower bound - this data could suggest even less utility. Because of the importance of this question, we are planning additional papers on other industries; as well as work on other approaches. 


\begin{tabular}{|c|c|c|c|c|c|c|c|c|c|c|c|c|c|c|}
\hline & & 2001 & 2000 & 1999 & 1998 & 1997 & 1996 & 1995 & 1994 & 1993 & 1992 & Average & Std.Dev. & Range \\
\hline \multirow{9}{*}{ 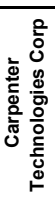 } & \multirow{5}{*}{$\begin{array}{l}\text { Net Equity Flow Method } \\
\text { Marginal Net Equity Flow Method } \\
\text { CAPM } \\
\text { WACC \& Net Equity Flow Method } \\
\text { WACC \& CAPM } \\
\end{array}$} & $4.8 \%$ & $6.5 \%$ & $4.9 \%$ & $3.0 \%$ & $3.3 \%$ & $4.5 \%$ & $4.0 \%$ & $4.5 \%$ & $4.9 \%$ & $5.3 \%$ & $4.6 \%$ & $1.0 \%$ & $3.6 \%$ \\
\hline & & $4.8 \%$ & $6.3 \%$ & $4.7 \%$ & $2.8 \%$ & $3.0 \%$ & $4.2 \%$ & $3.6 \%$ & $4.1 \%$ & $4.7 \%$ & $8.8 \%$ & $4.7 \%$ & $1.8 \%$ & $6.1 \%$ \\
\hline & & $10.2 \%$ & $10.9 \%$ & $9.8 \%$ & $10.6 \%$ & $11.3 \%$ & $11.0 \%$ & $12.1 \%$ & $10.8 \%$ & $11.1 \%$ & $12.2 \%$ & $11.0 \%$ & $0.7 \%$ & $2.4 \%$ \\
\hline & & $4.7 \%$ & $6.2 \%$ & $5.0 \%$ & $3.4 \%$ & $3.8 \%$ & $4.7 \%$ & $4.3 \%$ & $4.7 \%$ & $4.9 \%$ & $5.4 \%$ & $4.7 \%$ & $0.8 \%$ & $2.7 \%$ \\
\hline & & $8.3 \%$ & $9.1 \%$ & $8.2 \%$ & $8.2 \%$ & $9.1 \%$ & $9.1 \%$ & $9.5 \%$ & $8.9 \%$ & $8.7 \%$ & $9.9 \%$ & $8.9 \%$ & $0.6 \%$ & $1.7 \%$ \\
\hline & \multirow{4}{*}{$\begin{array}{l}\text { Average } \\
\text { Standard Deviation } \\
\text { Range }\end{array}$} & $6.6 \%$ & $\begin{array}{l}7.8 \% \\
\end{array}$ & $6.5 \%$ & $5.6 \%$ & $6.1 \%$ & $6.7 \%$ & $\begin{array}{l}6.7 \% \\
\end{array}$ & $26.6 \%$ & $26.9 \%$ & $\begin{array}{l}8.3 \% \\
\end{array}$ & & & \\
\hline & & $2.5 \%$ & $2.1 \%$ & $2.3 \%$ & $3.6 \%$ & $3.8 \%$ & $3.1 \%$ & $3.8 \%$ & $3.0 \%$ & $2.9 \%$ & $3.0 \%$ & & & \\
\hline & & $5.5 \%$ & $4.8 \%$ & $5.1 \%$ & $7.8 \%$ & $8.3 \%$ & $6.8 \%$ & $8.5 \%$ & $6.7 \%$ & $6.4 \%$ & $7.0 \%$ & & & \\
\hline & & & & & & & & & & & & Average & Std.Dev. & Range \\
\hline \multirow{9}{*}{ 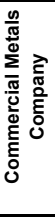 } & \multirow{5}{*}{$\begin{array}{l}\text { Net Equity Flow Method } \\
\text { Marginal Net Equity Flow Method } \\
\text { CAPM } \\
\text { WACC \& Net Equity Flow Method } \\
\text { WACC \& CAPM } \\
\end{array}$} & $1.7 \%$ & $1.9 \%$ & $1.7 \%$ & $2.2 \%$ & $10.1 \%$ & $1.6 \%$ & $6.1 \%$ & $1.8 \%$ & $1.4 \%$ & $2.3 \%$ & $3.1 \%$ & $2.8 \%$ & $8.7 \%$ \\
\hline & & $1.7 \%$ & $1.9 \%$ & $1.7 \%$ & $2.1 \%$ & $10.0 \%$ & $1.6 \%$ & $6.1 \%$ & $1.8 \%$ & $1.4 \%$ & $2.3 \%$ & $3.1 \%$ & $2.8 \%$ & $8.6 \%$ \\
\hline & & $8.7 \%$ & $9.5 \%$ & $8.5 \%$ & $9.1 \%$ & $9.9 \%$ & $9.6 \%$ & $10.5 \%$ & $9.7 \%$ & $9.6 \%$ & $10.6 \%$ & $9.6 \%$ & $0.7 \%$ & $2.1 \%$ \\
\hline & & $2.7 \%$ & $3.0 \%$ & $2.9 \%$ & $2.8 \%$ & $8.3 \%$ & $2.6 \%$ & $5.8 \%$ & $2.6 \%$ & $2.1 \%$ & $3.1 \%$ & $3.6 \%$ & $1.9 \%$ & $6.1 \%$ \\
\hline & & $7.3 \%$ & $7.9 \%$ & $7.2 \%$ & $7.6 \%$ & $8.2 \%$ & $8.2 \%$ & $8.7 \%$ & $8.8 \%$ & $8.4 \%$ & $9.1 \%$ & $8.1 \%$ & $0.6 \%$ & $1.9 \%$ \\
\hline & \multirow{4}{*}{$\begin{array}{l}\text { Average } \\
\text { Standard Deviation } \\
\text { Range }\end{array}$} & $4.4 \%$ & $4.8 \%$ & $4.4 \%$ & $\begin{array}{l}4.8 \% \\
\end{array}$ & 9.3\% & $4.7 \%$ & $\begin{array}{l}7.4 \% \\
\end{array}$ & $24.9 \%$ & $24.6 \%$ & $5.5 \%$ & & & \\
\hline & & $3.3 \%$ & $3.6 \%$ & $3.2 \%$ & $3.3 \%$ & $1.0 \%$ & $3.9 \%$ & $2.1 \%$ & $4.0 \%$ & $4.1 \%$ & $4.0 \%$ & & & \\
\hline & & $7.0 \%$ & $7.7 \%$ & $6.8 \%$ & $6.9 \%$ & $1.9 \%$ & $8.0 \%$ & $4.8 \%$ & $7.9 \%$ & $8.2 \%$ & $8.4 \%$ & & & \\
\hline & & & & & & & & & & & & Average & Std.Dev. & Range \\
\hline \multirow{9}{*}{ 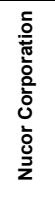 } & \multirow{5}{*}{$\begin{array}{l}\text { Net Equity Flow Method } \\
\text { Marginal Net Equity Flow Method } \\
\text { CAPM } \\
\text { WACC \& Net Equity Flow Method } \\
\text { WACC \& CAPM } \\
\end{array}$} & $15.0 \%$ & $15.2 \%$ & $11.8 \%$ & $22.1 \%$ & $23.4 \%$ & $22.2 \%$ & $46.2 \%$ & $13.2 \%$ & $0.3 \%$ & $0.4 \%$ & $17.0 \%$ & $13.1 \%$ & $45.9 \%$ \\
\hline & & $15.0 \%$ & $15.2 \%$ & $11.8 \%$ & $22.1 \%$ & $23.4 \%$ & $22.2 \%$ & $46.2 \%$ & $13.2 \%$ & $0.3 \%$ & $0.4 \%$ & $17.0 \%$ & $13.1 \%$ & $45.9 \%$ \\
\hline & & $12.5 \%$ & $13.5 \%$ & $13.1 \%$ & $12.7 \%$ & $13.8 \%$ & $13.9 \%$ & $14.0 \%$ & $14.5 \%$ & $13.3 \%$ & $14.5 \%$ & $13.6 \%$ & $0.7 \%$ & $2.1 \%$ \\
\hline & & $13.5 \%$ & $13.6 \%$ & $10.8 \%$ & $20.5 \%$ & $21.8 \%$ & $20.7 \%$ & $43.2 \%$ & $12.2 \%$ & $1.5 \%$ & $4.4 \%$ & $16.2 \%$ & $11.6 \%$ & $41.7 \%$ \\
\hline & & $11.3 \%$ & $12.2 \%$ & $11.9 \%$ & $11.9 \%$ & $13.0 \%$ & $13.1 \%$ & $13.3 \%$ & $13.3 \%$ & $11.0 \%$ & $7.8 \%$ & $11.9 \%$ & $1.7 \%$ & $5.5 \%$ \\
\hline & Average & $13.5 \%$ & $\begin{array}{l}13.9 \% \\
\end{array}$ & $11.9 \%$ & $\overline{17.9 \%}$ & $19.1 \%$ & $18.4 \%$ & $32.6 \%$ & $13.3 \%$ & $5.3 \%$ & $5.5 \%$ & & & \\
\hline & Standard Deviation & $1.6 \%$ & $1.3 \%$ & $0.8 \%$ & $5.1 \%$ & $5.2 \%$ & $4.5 \%$ & $17.3 \%$ & $0.8 \%$ & $6.3 \%$ & $5.9 \%$ & & & \\
\hline & Range & $3.7 \%$ & $3.0 \%$ & $2.2 \%$ & $10.2 \%$ & $10.3 \%$ & $9.1 \%$ & $32.8 \%$ & $2.3 \%$ & $13.0 \%$ & $14.1 \%$ & & & \\
\hline & & & & & & & & & & & & Average & Std.Dev. & Range \\
\hline \multirow{9}{*}{ 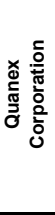 } & \multirow{5}{*}{$\begin{array}{l}\text { Net Equity Flow Method } \\
\text { Marginal Net Equity Flow Method } \\
\text { CAPM } \\
\text { WACC \& Net Equity Flow Method } \\
\text { WACC \& CAPM }\end{array}$} & $2.5 \%$ & $3.3 \%$ & $3.0 \%$ & $8.8 \%$ & $3.9 \%$ & $3.9 \%$ & $8.5 \%$ & $4.2 \%$ & $9.4 \%$ & $9.8 \%$ & $5.7 \%$ & $3.0 \%$ & $7.4 \%$ \\
\hline & & $2.5 \%$ & $3.5 \%$ & $3.0 \%$ & $9.0 \%$ & $3.9 \%$ & $3.8 \%$ & $8.4 \%$ & $2.3 \%$ & $0.0 \%$ & $2.8 \%$ & $3.9 \%$ & $2.8 \%$ & $9.0 \%$ \\
\hline & & $8.8 \%$ & $9.8 \%$ & $9.1 \%$ & $9.1 \%$ & $10.1 \%$ & $10.0 \%$ & $10.6 \%$ & $10.4 \%$ & $9.7 \%$ & $10.7 \%$ & $9.8 \%$ & $0.7 \%$ & $2.0 \%$ \\
\hline & & $3.7 \%$ & $4.1 \%$ & $3.9 \%$ & $7.0 \%$ & $4.3 \%$ & $4.2 \%$ & $6.7 \%$ & $4.5 \%$ & $7.5 \%$ & $8.1 \%$ & $5.4 \%$ & $1.7 \%$ & $4.4 \%$ \\
\hline & & $6.7 \%$ & $7.9 \%$ & $7.6 \%$ & $7.1 \%$ & $7.7 \%$ & $6.9 \%$ & $7.9 \%$ & $8.5 \%$ & $7.7 \%$ & $8.7 \%$ & $7.7 \%$ & $0.7 \%$ & $2.0 \%$ \\
\hline & \multirow{4}{*}{\begin{tabular}{|l} 
Average \\
Standard Deviation \\
Range
\end{tabular}} & $4.8 \%$ & $5.7 \%$ & $5.3 \%$ & $8.2 \%$ & $6.0 \%$ & $5.8 \%$ & $8.4 \%$ & $6.0 \%$ & $6.9 \%$ & $8.0 \%$ & & & \\
\hline & & $2.8 \%$ & $3.0 \%$ & $2.8 \%$ & $1.1 \%$ & $2.8 \%$ & $2.7 \%$ & $1.4 \%$ & $3.3 \%$ & $4.0 \%$ & $3.1 \%$ & & & \\
\hline & & $6.3 \%$ & $6.5 \%$ & $6.1 \%$ & $2.2 \%$ & $6.2 \%$ & $6.2 \%$ & $3.9 \%$ & $8.1 \%$ & $9.7 \%$ & $7.9 \%$ & & & \\
\hline & & & & & & & & & & & & Average & Std.Dev. & Range \\
\hline \multirow{8}{*}{ 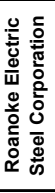 } & \multirow{5}{*}{$\begin{array}{l}\text { Net Equity Flow Method } \\
\text { Marginal Net Equity Flow Method } \\
\text { CAPM } \\
\text { WACC \& Net Equity Flow Method } \\
\text { WACC \& CAPM }\end{array}$} & $3.4 \%$ & $6.6 \%$ & $7.3 \%$ & $2.6 \%$ & $13.7 \%$ & $24.9 \%$ & $2.4 \%$ & $30.8 \%$ & $3.7 \%$ & $4.7 \%$ & $10.0 \%$ & $10.1 \%$ & $28.4 \%$ \\
\hline & & $3.6 \%$ & $6.6 \%$ & $7.3 \%$ & $2.6 \%$ & $13.7 \%$ & $24.8 \%$ & $2.4 \%$ & $30.8 \%$ & $3.6 \%$ & $4.7 \%$ & $10.0 \%$ & $10.0 \%$ & $28.4 \%$ \\
\hline & & $7.7 \%$ & $8.7 \%$ & $8.0 \%$ & $8.0 \%$ & $9.0 \%$ & $8.9 \%$ & $9.5 \%$ & $9.3 \%$ & $8.6 \%$ & $9.7 \%$ & $8.7 \%$ & $0.7 \%$ & $2.0 \%$ \\
\hline & & $4.0 \%$ & $5.8 \%$ & $6.1 \%$ & $2.9 \%$ & $11.6 \%$ & $19.3 \%$ & $2.8 \%$ & $24.3 \%$ & $3.9 \%$ & $4.9 \%$ & $8.6 \%$ & $7.5 \%$ & $21.4 \%$ \\
\hline & & $6.5 \%$ & $7.0 \%$ & $6.4 \%$ & $7.3 \%$ & $8.0 \%$ & $7.8 \%$ & $8.6 \%$ & $8.3 \%$ & $7.3 \%$ & $8.4 \%$ & $7.6 \%$ & $0.8 \%$ & $2.2 \%$ \\
\hline & Average & $5.0 \%$ & $6.9 \%$ & $7.0 \%$ & $4.7 \%$ & $11.2 \%$ & $17.2 \%$ & $5.2 \%$ & $20.7 \%$ & $5.4 \%$ & $6.5 \%$ & & & \\
\hline & Standard Deviation & $1.9 \%$ & $1.1 \%$ & $0.8 \%$ & $2.7 \%$ & $2.6 \%$ & $8.3 \%$ & $3.6 \%$ & $11.2 \%$ & $2.4 \%$ & $2.4 \%$ & & & \\
\hline & Range & $4.3 \%$ & $2.9 \%$ & $1.9 \%$ & $5.5 \%$ & $5.7 \%$ & $17.1 \%$ & $7.1 \%$ & $22.5 \%$ & $5.0 \%$ & $5.0 \%$ & & & \\
\hline
\end{tabular}

Table 4 -Calculation Results

Proceedings of the 2003 American Society for Engineering Education Annual Conference \& Exposition (ङ) 2003, American Society for Engineering Education 


\section{Bibliography}

${ }^{1}$ Prescott, Lisa, John Whittaker, and Ted Eschenbach, "Shifting $i$ 's Are Not A Firm Foundation." Proceedings of the American Society for Engineering Management 22nd Annual National Conference, Tampa, Oct. 2-6, 2002. pp. 303-307

${ }^{2}$ Prescott, Lisa, The Minimum Acceptable Rate of Returm: Engineering Economic Theory and Practice. M.Sc. Thesis, University of Alberta Department of Mechanical Engineering, Fall (1999).

${ }^{3}$ Park, Chan S., Kenneth C. Porteous, Kenneth F. Sadler, and Ming J. Zuo, Contemporary Engineering Economics: A Canadian Perspective, Addison-Wesley Publishers Limited (1995).

${ }^{4}$ Kellison, Stephen G., The Theory of Interest, $2^{\text {nd }}$, Irwin (1991).

${ }^{5}$ Ross, Stephen A., Randolph W. Westerfield, and Jeffrey F. Jaffe, Gordon S. Roberts, Corporate Finance, $1^{\text {st }}$ Canadian Edition, Irwin (1995).

${ }^{6}$ Weston, J. Fred, Juan A. Siu, and Brian A. Johnson, Takeovers, Restructuring and Corporate Governance, $2^{\text {nd }}$, Prentice-Hall (1998).

${ }^{7}$ Stewart, G. Bennett III, The Quest for Value: The EVA Management Guide, USA: Harper Collins (1991).

${ }^{8}$ Dierks, Paul A., and Ajay Patel, "What is EVA, and How Can it Help Your Company?", Management Accounting, Vol. 79, No. 5, (Nov. 1997), pp. 52-58.

\section{Biographical Data}

MIKE LOOSE received his B.Sc. in mechanical engineering from the University of Alberta in 2002. He is currently enrolled in the master of engineering in engin eering management program at the University of Alberta and doing research in the area of the cost of capital and MARR.

TED ESCHENBACH, P.E. received the Ph.D. in industrial engineering from Stanford in 1975 and his MCE from the University of Alaska Anchorage in 1998. He is an emeritus professor of engineering management at UAA and the founding editor emeritus of the Engineering Management Journal (1988 until early 2002). He is the author or co-author of 5 texts in engineering economy and one on the future of Alaska.

JOHN WHITTAKER received his Ph.D. in administrative sciences from The City University, London, UK in 1971 and his SM in civil engineering from MIT in 1963. He is a professor of engineering management at the University of Alberta. He has taught and worked on 4 continents. His research interests evolve around the issue of engineering productivity. He authored texts in engineering economy and wine making, as well as a series of picnicking guides. 